\section{Management of Primocane-fruiting Blackberry: Impacts on Yield, Fruiting Season, and Cane Architecture}

\author{
Bernadine C. Strik ${ }^{1,2}$ \\ Department of Horticulture, Oregon State University, 4017 ALS, Corvallis, \\ OR 97331
}

John R. Clark
Department of Horticulture, University of Arkansas, Plant Science 316,
Fayetteville, AR 72701

Chad E. Finn

U.S. Department of Agriculture, Agricultural Research Service, Horticultural Crops Research Laboratory, 3420 NW Orchard Avenue, Corvallis, OR 97330

\section{Gil Buller}

North Willamette Research and Extension Center, 15210 NE Miley Road, Aurora, OR 97002

Additional index words. Rubus, 'Prime-Jan' ${ }^{\circledR}$, 'Prime-Jim' ${ }^{\circledR}$, summer pruning, fruit size, tipping, yield components

Abstract. Primocane management systems were compared for 'Prime-Jan'® ${ }^{\circledR}$ and 'PrimeJim $^{\circledR}$, primocane-fruiting blackberry (Rubus L. subgenus Rubus, Watson), grown in a field planting in Aurora, OR. Treatments studied were: 1) no manipulation of primocanes (untipped; no floricanes); 2) untipped primocanes growing in the presence of floricanes; 3 ) untipped primocanes grown with rowcover in late winter to early spring; and 4) primocanes "soft-tipped" at $1 \mathrm{~m}$ to encourage branching. Date of primocane first bloom and cane height at bloom were unaffected by cultivar and were only affected by primocane management in 2005 . The number of growing degree-days to first bloom ranged from 1272 to 1390 depending on year. Primocane management did not affect ovule or drupelet number per berry or percent drupelet set. 'Prime-Jim' had more drupelets and greater weight per berry in 2005 than 'Prime-Jan'. Fruit harvested earlier in the season had more ovules and drupelets than later harvested fruit in 2004. Primocanes that grew in the presence of floricanes were longer and bloomed later but did not differ in yield from untipped canes grown only for a primocane crop. Use of rowcover in 2005 advanced bloom and harvest, improving yield $73 \%$ compared with untipped control canes. Soft-tipping primocanes increased yield $114 \%$ to $150 \%$ compared with untipped canes (5.6 vs. $\left.2.4 \mathrm{t} \cdot \mathrm{ha}^{-1}\right)$ through increasing branch and node number per cane and percentage of fruiting nodes; soft-tipping did not delay harvest. Yield/cane was negatively correlated with the number of fruiting canes/plot but positively correlated with branches/cane, total branch and cane length, number of nodes and percent fruiting nodes, fruit/cane, and berry weight. The proportion of fruiting nodes was greater on branches than on the main cane illustrating the importance of managing this type of blackberry to increase branch number for high yield.

Primocane-fruiting blackberries released by the University of Arkansas (Clark et al., 2005; Clark and Perkins-Veazie, 2011) offer an alternative or addition to the other types of high-value, fresh-market blackberries avail-

Received for publication 7 Feb. 2012. Accepted for publication 13 Mar. 2012.

We appreciate research funding support provided by the Oregon Raspberry and Blackberry Commission and the Agricultural Research Foundation and the assistance provided by Ellen Thompson in the second year of this study.

${ }^{1}$ Professor.

${ }^{2}$ To whom reprint requests should be addressed; e-mailstrikb@hort.oregonstate.edu. season can be modified by advancing or delaying primocane growth using rowcovers (Pritts et al., 1992) and can be easily manipulated to produce fruit at most times of the year in warm climates and/or tunnels to target high-priced niche markets (Darnell et al., 2006; Oliveira et al., 1996, 1998).

Cultural practices may be used to manipulate the fruiting season of primocanefruiting blackberries. Use of spun-bound rowcover from late winter through early spring advanced flowering and fruiting in Oregon (Strik et al., 2008) but had no impact in North Carolina (Fernandez and Ballington, 2010). In plants in which primocanes were mowed back to ground level when height averaged $\approx 0.5 \mathrm{~m}$, fruit production was delayed by $\approx 4$ weeks (Thompson et al., 2009). Producing primocanefruiting blackberry in an unheated tunnel extended the harvest season $\approx 3$ weeks later in the fall in Oregon's temperate climate (Thompson et al., 2009).

Research in primocane-fruiting raspberry showed that primocane tipping had some effect on fruiting season and yield. "Hard tipping" (removal of $0.3 \mathrm{~m}$ ) 'Heritage' primocanes to $1 \mathrm{~m}$ delayed fruiting (Jordan and Ince, 1986; Richter et al., 1989). Oliveira et al. (1998) found that summer tipping advanced harvest in primocane-fruiting raspberry compared with plants that were recut to ground level, but they did not have an untipped control for comparison. Tipping canes later in the season reduced yield. In primocanefruiting blackberry, the effects of "softtipping" (removal of 2 to $5 \mathrm{~cm}$ ) individual primocanes on yield and berry size depended on when the tipping was done (Drake and Clark, 2003). They suggested that other tipping treatments and studies in a milder climate than that of Arkansas would be beneficial to development of a production system for this new crop. Soft-tipping the primocane at $1 \mathrm{~m}$ induced branching and increased flower and fruit number and yield threefold without affecting fruiting season in Oregon (Strik et al., 2008). A double tip, where branches are further shortened, has been shown to increase yield compared with untipped canes (Thompson et al., 2009). A better understanding of the impact of primocane management on cane architecture and yield components may advance production systems of genotypes in various climates.

The objectives of this study were to determine the impact of primocane tipping in summer, the presence of floricanes, and the use of rowcover on the fruiting season, yield, fruit size, cane architecture, and yield components of primocane-fruiting blackberry.

\section{Materials and Methods}

Tissue-cultured plugs of 'Prime-Jan' ${ }^{\circledR}$ and 'Prime-Jim' ${ }^{\circledR}$ were planted 3 June 2003 at Oregon State University's North Willamette Research and Extension Center, Aurora, OR [long. $45^{\circ} 17^{\prime} \mathrm{N}$, lat. $122^{\circ} 45^{\prime} \mathrm{W}$; U.S. Dept. of Agriculture hardiness zone 8; elevation $46 \mathrm{~m}$ above sea level; average last freeze date 17 Apr.; average first freeze date 25 Oct.; 
weather records for this site can be viewed at Anonymous (2012)]. The soil type was a Quatama loam (fine-loamy, mixed, mesic Aqualtic Haploxeralfs). Plants were spaced $0.6 \mathrm{~m}$ in the row with $3 \mathrm{~m}$ between rows. Five-plant plots were $3 \mathrm{~m}$ long with $3 \mathrm{~m}$ separating plots.

The field was drip-irrigated $\left(3.8 \mathrm{~L} \cdot \mathrm{h}^{-1}\right.$ emitters at $0.6-\mathrm{m}$ spacing) as required, typically 30 min twice daily from June through September. Plots were fertilized with 55 $\mathrm{kg} \cdot \mathrm{ha}^{-1}$ nitrogen $(\mathrm{N}), 35 \mathrm{~kg} \cdot \mathrm{ha}^{-1}$ phosphorus, and $66 \mathrm{~kg} \cdot \mathrm{ha}^{-1}$ potassium each spring and an additional $28 \mathrm{~kg} \cdot \mathrm{ha}^{-1} \mathrm{~N}$ at primocane bloom in June. Weeds were controlled with preemergent herbicides and mechanical methods. Blackberry row width was maintained at $0.45 \mathrm{~m}$ using cultivation. Canes were trained between double sets of trellis wires located at $0.3 \mathrm{~m}$ and $1.7 \mathrm{~m}$ high but were not tied to the wires.

There were four replicates of the following treatments arranged as a randomized complete block design: 1) no manipulation of primocanes [untipped ("UT")]; 2) untipped primocanes growing in the presence of floricanes [affected by floricane crop ("UT+F")]; 3) rowcovers used in late winter to early spring to advance primocane growth and primocanes untipped ("UTR"); and 4) primocanes "soft-tipped" (2 to $5 \mathrm{~cm}$ of the tip removed) at $1 \mathrm{~m}$ to encourage branching ("tipped"). Treatments 1, 3, and 4 only included the primocane crop. Management treatments were arranged in a full factorial design with Prime-Jan ${ }^{\circledR}$ and Prime-Jim ${ }^{\circledR}$. Primocanes were tipped (Treatment 4 ) before there was any evidence of flower buds at the tip of the cane; "soft-tipping" after inflorescences have appeared has been shown to reduce yield and berry weight (Drake and Clark, 2003; Strik, personal observation). The $\mathrm{UT}+\mathrm{F}$ treatment could only be studied in 2005 , because there were no floricanes present in 2004.

In the planting year, plants grew untrained and unmanipulated. In Spring 2004, the short floricanes were removed from all plants and the primocane treatments (1-4) were initiated. There was no floricane crop in 2004, so only Treatments 1,3 , and 4 were evaluated. Primocanes were not thinned in 2004-2005. In Winter 2004-2005, the primocanes were removed from all treatments by cutting at ground level with the exception of those in treatment $\mathrm{UT}+\mathrm{F}$ in which the untipped primocanes were allowed to overwinter, unpruned, to produce the floricane crop in 2005. All treatments (1-4) were compared in 2005.

In the tipped treatment, primocanes were soft-tipped to $1 \mathrm{~m}$ during the growing season from 1 to 14 June 2004 and 15 to 29 June 2005 to catch the various flushes of cane growth; the 2005 season was cooler than in 2004 (Fig. 1). In treatment UTR, rowcovers ( $5 \mathrm{~mm}$, white spun bound polyester $85 \%$ transparent, 1.1 to $2.2{ }^{\circ} \mathrm{C}$; Reemay, Inc., Old Hickory, TN) were placed over the plots before primocane emergence (observed in late February in 2004 and 2005) and removed when primocanes got too tall for unimpaired growth under the cover $(\approx 0.30$ to $0.45 \mathrm{~m}$ tall $)$; dates for rowcover treatments were 31 Mar. to

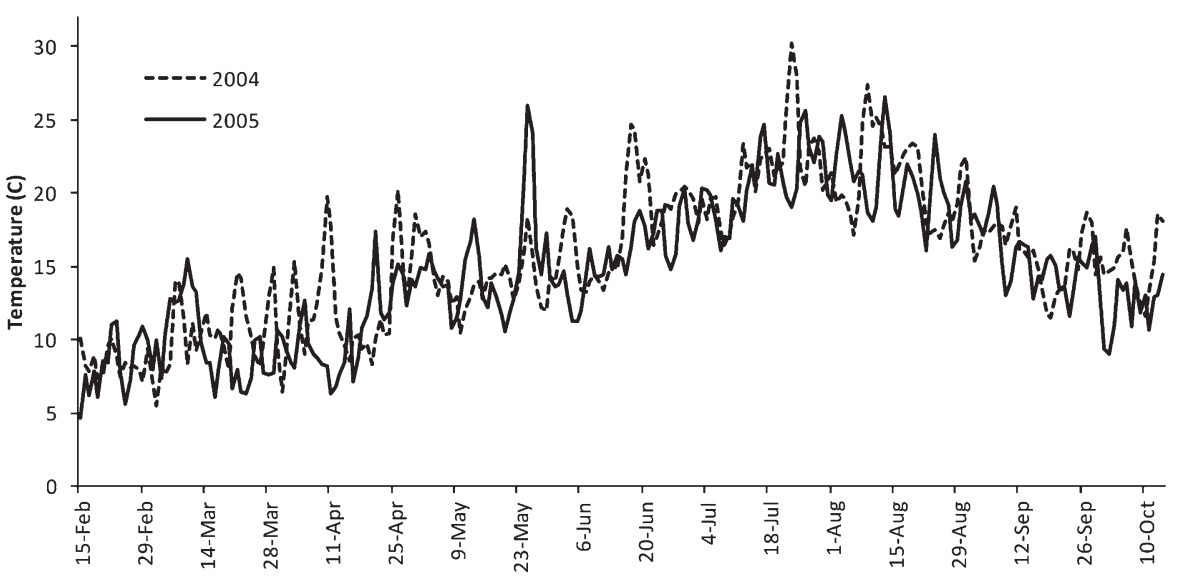

Fig. 1. Average air temperature $\left({ }^{\circ} \mathrm{C}\right.$; hourly, $\left.24 \mathrm{~h}\right)$ from mid-February to mid-Oct. 2004 and 2005 at Oregon State University's North Willamette Research and Extension Center.

3 May 2004 and 22 Feb. to 20 Apr. 2005. In 2005, Hobo $8 \mathrm{~K}$ four-channel data loggers (Onset Computer Corp., Bourne, MA) were used to measure soil and air temperatures under the rowcovers and in uncovered adjacent plots.

The data collected per plot included date of first bloom (four open flowers on at least four separate canes/plot), primocane height at flowering (on four canes/plot), date of first black fruit (four fully black fruit on at least four separate canes/plot), marketable yield (harvested every $7 \mathrm{~d}$ ), weight of non-marketable fruit, average berry weight ( 25 berries per harvest date), date of first and last harvest, and cane growth (measured every 2 weeks on three canes/plot). Subsamples of fruit $(n=5)$ from each treatment plot were collected on an early and late harvest date in each year and frozen for later counts of set drupelets and unset ovules. The total number of ovules per flower was estimated by adding the number of drupelets and unset ovules (Strik et al., 1996).

The number of growing degree-days (GDD) was recorded using a base of $10^{\circ} \mathrm{C}$ and an upper cap of $30^{\circ} \mathrm{C}$ (Anonymous, 2012). In late October, the number of fruiting and vegetative primocanes/plot was recorded. A subsample of three fruiting primocanes/plot was collected and data recorded on: number of branches, total branch length, total number of nodes (main cane + branches), total number of reproductive nodes (nodes that bore a flower bud or fruiting lateral), and total number of fruiting sites per cane (remnant pedicels of floral axes were counted where fruit excision was evident). The percentage of reproductive nodes (proportion of nodes that developed a flower bud or fruiting lateral) was calculated.

Analysis of variance was performed for year and treatment effects using PROC MIXED in SAS Version 9.1 (SAS Institute Inc., Cary, NC). The effects of cultivar, treatment, and harvest date on ovule and drupelet number were analyzed using PROC MIXED. Means were separated at the $P=0.05$ level using Duncan's new multiple range test. Primocane growth was analyzed by repeated-measures analysis of variance by year and yield was correlated with various components using PROC CORR in SAS.

\section{Results and Discussion}

Primocane growth. The 2004 growing season was warmer than the 2005 growing season (Fig. 1). Primocane growth was affected by cultivar and primocane management treatment in both years; the UT primocanes of 'Prime-Jan' were shorter at the end of the season than those of 'Prime-Jim' (1.9 m vs. $2.3 \mathrm{~m}$, on average, respectively; $P=0.016$; data not shown). The primocanes of 'PrimeJan' (data not shown) and 'Prime Jim' (Fig. 2) stopped growing at the end of July in 2004 (1780 GDD) or by mid-August in 2005 (1910 GDD). In 2004 and 2005, by the end of the season, tipped canes had less total growth on average $(1.5 \mathrm{~m})$ than UT canes $(2.1 \mathrm{~m})$, although branches were included in the measurements $(P=0.034$ and $P=0.023$, respectively). In 2005, untipped primocanes that grew in the presence of floricanes $(\mathrm{UT}+\mathrm{F})$ were significantly longer $(2.5 \mathrm{~m})$ than UT canes without floricanes retained $(2.1 \mathrm{~m})$ in both cultivars $(P=0.023$; Fig. 2$)$.

Primocanes in the UTR treatment were not longer than the control (UT) primocanes by the end of the season in either cultivar (Fig. 2). Although the soil and air temperature under the rowcover averaged $2{ }^{\circ} \mathrm{C}$ warmer than the control (data not shown) and advanced early primocane growth in this study, the difference in primocane height was not maintained through the season as reported in primocane-fruiting red raspberry (Pritts et al., 1992).

Bloom and harvest season. Date of first bloom on the primocanes and cane height at first bloom were unaffected by cultivar in either year and were only affected by primocane management treatment in 2005 (data not shown). Primocanes averaged $1.5 \mathrm{~m}$ in total length at first bloom (four open flowers) on 14 July 2004 (1390 GDD) and first black fruit were observed on 20 Aug. 2004 (2179 GDD). In 2005 , primocanes in the UT $+F$ treatment averaged $2.2 \mathrm{~m}$ in height at bloom, significantly $(P<0.0001)$ taller than the other treatments 

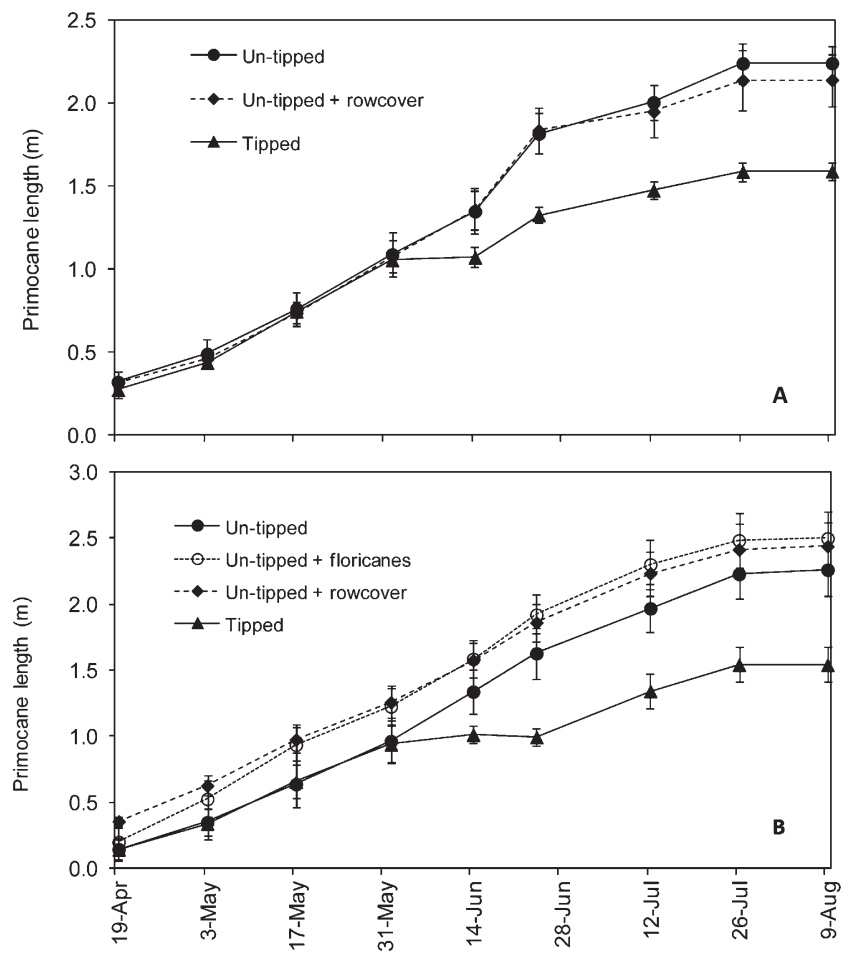

Fig. 2. The effect of pruning management on primocane growth of 'Prime-Jim' blackberry in 2004 (A) and 2005 (B) in Oregon. There were no floricanes in 2004; thus, this treatment was omitted. In the "tipped" treatment, primocane tipping occurred from 1 to 14 June 2004 and 15 to 29 June 2005 (to catch various flushes of cane growth). Mean $\pm \operatorname{SE}(n=4)$.

(average $1.3 \mathrm{~m}$ ). Primocanes in the $\mathrm{UT}+\mathrm{F}$ treatment had first bloom on 22 July (1408 GDD), $8 \mathrm{~d}$ later than the UT and tipped primocanes (1272 GDD).

Use of rowcovers in 2005 advanced the bloom of the UTR canes $14 \mathrm{~d}$ (24 June) compared with UT canes in both cultivars $(P=0.001)$. Primocanes grew faster than those without rowcover and thus bloomed earlier. In New York State, when rowcovers were placed over 'Heritage' red raspberry from before primocane emergence to a primocane height of $\approx 0.5 \mathrm{~m}$ tall, harvest was advanced by as much as 3 weeks and yield increased compared with uncovered plants (Pritts et al., 1992). Similar to our study, the advanced harvest allowed more of the crop to be harvested. In primocane-fruiting red raspberry, rate of growth and flowering was increased with temperature (Carew et al., 2003; Sønsteby and Heide, 2009). Primocanefruiting blackberries growing from root cuttings initiated flower buds after a short period of growth $(\approx 20$ nodes $)$ and the terminal flower opened $\approx 35 \mathrm{~d}$ after floral initiation (Lopez-Medina et al., 1999). In our study, primocanes grew faster and flowered sooner under the warmer temperatures found in 2004 (vs. 2005) and when rowcovers were used in 2005. We suspect that the rapid rate of growth in our study promoted earlier flower bud initiation and development. Rowcover did not affect bloom date in 2004, likely because the rowcover was not applied early or long enough to significantly advance growth. In North Carolina, rowcover did not advance the fruiting season (Fernandez and Ballington,
2010); however, rowcover was removed when primocanes were $\approx 0.15 \mathrm{~m}$ tall compared with 0.30 to $0.45 \mathrm{~m}$ in our study.

The number of days from first bloom to first black fruit was unaffected by cultivar or treatment and averaged 36 and 43 d in 2004 and 2005 , respectively (data not shown), a little less than the 45- to 51-d range reported by Thompson et al. (2007). Date of first black fruit ranged from 14 Aug. in the UTR to 5 Sept. 2005 (2266 GDD) in the UT+F treatments.

Although black fruit were first observed from mid-August to early September, depending on treatment and year, the progression of ripe fruit was slow with only $1 \%$ to $7 \%$ of total yield harvested in 'Prime-Jim' and $0.5 \%$ to $1.5 \%$ in 'Prime-Jan' on 16 Aug. 2004. In 2005, only $0 \%$ to $1.5 \%$ of total yield was harvested on 15 Aug. for both cultivars.

The date at which $1.0 \mathrm{~kg} /$ plot cumulative yield was harvested was also calculated to evaluate fruiting season. Although UT primocanes of 'Prime Jan' were 2 weeks later than those of 'Prime Jim', the tipped canes reached a cumulative yield of $1.0 \mathrm{~kg} / \mathrm{plot}$ on 30 Aug. 2004 in both cultivars. In 2004, the tipped and UTR treatments had a similar season and UT canes were the latest (Figs. 3A and C). In 2005 in 'Prime Jan', UTR treatment plots were the earliest, then tipped treatments, followed by the UT and UT $+\mathrm{F}$ treatments, which reached $1.0 \mathrm{~kg} / \mathrm{plot} \approx 2$ weeks later than the tipped plots (Fig. 3B). In 'Prime Jim', results were similar with the $\mathrm{UT}$ and $\mathrm{UT}+\mathrm{F}$ treatments $\approx 2$ weeks later than the UTR and tipped treatments (Fig. 3D). Drake and Clark (2003) found that tipping canes had no impact on harvest season and presence of floricanes had no impact on harvest date of the primocane.

Although date of first bloom was a good predictor for when to expect first black fruit, it was not useful at predicting rate of fruit ripening and yield progression. The number of GDD to harvest of $1.0 \mathrm{~kg} / \mathrm{plot}$ for UT primocanes was 2452 and 2469 for 2004 and 2005, respectively, for 'Prime Jan' and 2439 and 2613, respectively, for 'Prime Jim'. Air temperature from June to July was related to various yield components in primocane-fruiting raspberry (Privé et al., 1993). With only 2 years of data it is not possible to fully determine the relationship between GDD or air temperature and primocane growth, flowering, and fruiting season in our study.

We stopped picking in mid-October in both years (Fig. 3) as a result of rain, but at that time, there were still flower buds, flowers, and unripe fruit present on most treatments. A high tunnel would have allowed for much later harvest (Thompson et al., 2009) and would have protected fruit from sunburn, which was a problem in late August as a result of high temperatures and/or light intensity (data not shown).

Yield and berry weight. Year had a significant effect on all variables measured except for yield and percent fruiting nodes. There was no year-by-treatment interaction, but data are presented by year as the planting was maturing from 2004 to 2005 (Table 1). 'PrimeJan' had a higher yield/plot than 'Prime-Jim' in 2004, but there was no cultivar effect on yield in 2005 (Table 1). In 2004, yield/plot of 'Prime-Jan' was greater because of a higher yield/cane, not because of a higher cane density per plot; there was no effect of cultivar on the number of fruiting canes/plot and 'Prime-Jan' had shorter canes with fewer nodes than 'Prime-Jim' (Table 1). Total cane length was shorter in 2005 than in 2004, because the branches grew less in 2005. Although yield was similar among years, yield/cane was much lower in 2005 than in 2004. The lower yield/ cane in 2005 was related to shorter canes with fewer fruit/cane because percent fruiting nodes was unaffected by year (Table 1).

Tipping the primocanes led to a significantly higher yield (average of $5.6 \mathrm{t} \cdot \mathrm{ha}^{-1}$ ) than leaving canes untipped (average of 2.4 $\mathrm{t} \cdot \mathrm{ha}^{-1}$ ) in both years (Table 1 ). Our results differ from those reported by Drake and Clark (2003) in Arkansas who found no positive effect of early tipping on yield. Although this may still not be an economical yield, yield would likely have been much greater had we been able to harvest the entire crop, particularly in soft-tipped primocanes where there were still many flower buds, flowers, and unripe fruit present when harvest had to stop as a result of rain. Under tunnels, primocane yield of 'Prime-Jan' was more than $200 \%$ greater than in open-field production at the same research site (Thompson et al., 2009). In our study, the yield of 'PrimeJan' tipped at $1 \mathrm{~m}$ was $30 \%$ to $70 \%$ greater than for field-grown plants at the same site when canes were tipped at $0.5 \mathrm{~m}$ (Thompson 

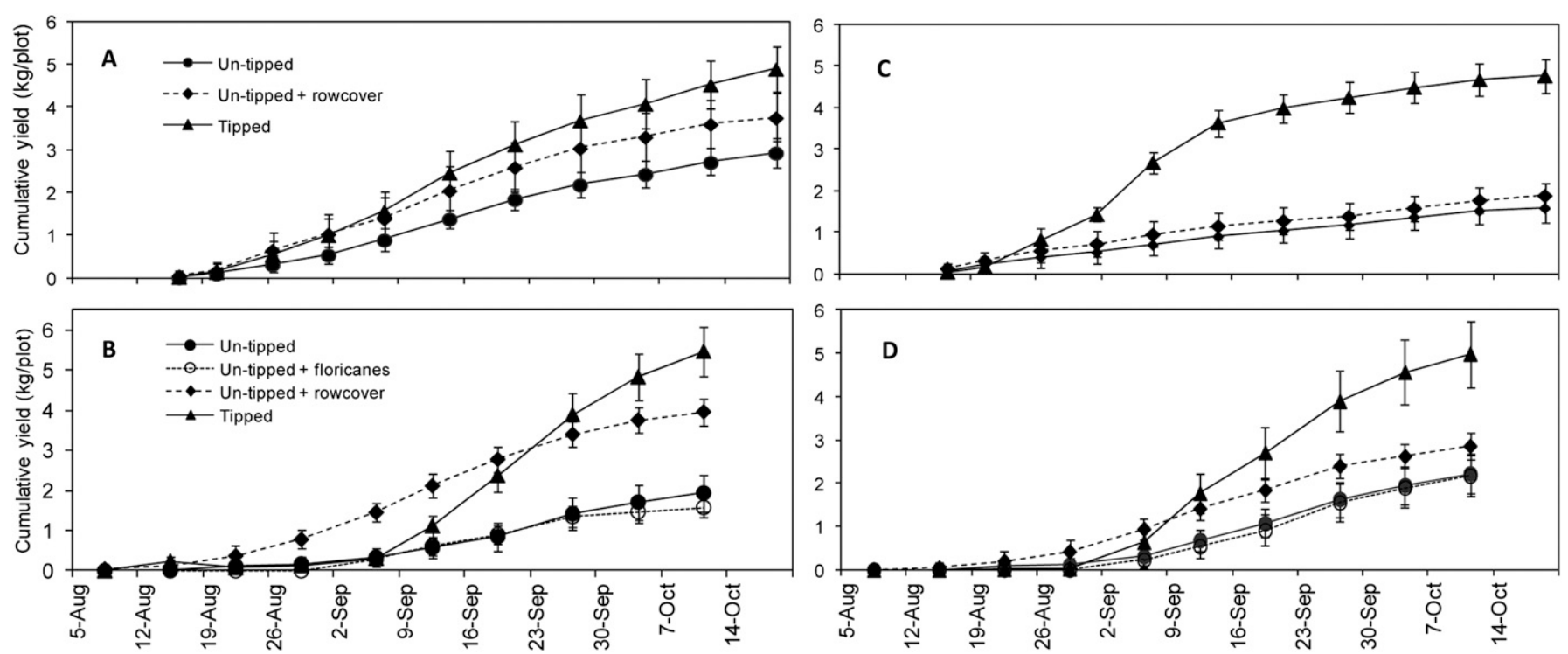

Fig. 3. Cumulative yield of primocane-fruiting blackberries 'Prime-Jan' in 2004 (A) and 2005 (B) and 'Prime-Jim” in 2004 (C) and 2005 (D) as affected by primocane management treatment in Oregon. There were no floricanes in 2004; thus, this treatment was omitted. Mean \pm SE.

Table 1. The effect of cultivar $(n=16)$ and primocane management system $(n=8)$ on yield components for primocane-fruiting blackberries in Oregon in 2004 and 2005.

\begin{tabular}{|c|c|c|c|c|c|c|c|c|c|}
\hline \multirow[b]{2}{*}{$\mathrm{Yr} /$ treatment } & \multirow{2}{*}{$\begin{array}{l}\text { Berry } \\
\text { wt (g) }\end{array}$} & \multirow{2}{*}{$\begin{array}{c}\text { Yield } \\
\text { (kg/plot) }\end{array}$} & \multirow{2}{*}{$\begin{array}{l}\text { Yield } \\
\text { (g/cane) }\end{array}$} & \multicolumn{2}{|c|}{ Canes/plot } & \multirow{2}{*}{$\begin{array}{l}\text { Total cane } \\
\text { length }(\mathrm{m})\end{array}$} & \multirow{2}{*}{$\begin{array}{c}\text { Total } \\
\text { no. nodes }\end{array}$} & \multirow{2}{*}{$\begin{array}{c}\text { Fruiting } \\
\text { nodes }(\%)\end{array}$} & \multirow{2}{*}{$\begin{array}{l}\text { Total no. } \\
\text { fruit/cane }\end{array}$} \\
\hline & & & & Fruiting & Vegetative & & & & \\
\hline \multicolumn{10}{|l|}{ Cultivar } \\
\hline \multicolumn{10}{|l|}{ Primocane management } \\
\hline Untipped & $6.3 \mathrm{a}^{\mathrm{w}}$ & $2.26 \mathrm{a}$ & $184 \mathrm{a}$ & $12.6 \mathrm{a}$ & $12.9 \mathrm{a}$ & 5.63 & 142.5 & $30.0 \mathrm{a}$ & 103.0 \\
\hline Primocanes + floricanes $\mathrm{s}^{\mathrm{y}}$ & - & - & - & - & - & - & - & - & - \\
\hline \multicolumn{10}{|l|}{ Significance $^{\mathrm{x}}$} \\
\hline Cultivar (C) & $* * *$ & $* * *$ & $* * *$ & NS & $* *$ & $*$ & $*$ & NS & NS \\
\hline Management (M) & * & $* * *$ & *** & ** & $*$ & NS & NS & $* * *$ & NS \\
\hline $\mathrm{C} \times \mathrm{M}$ & NS & NS & NS & NS & NS & NS & NS & NS & NS \\
\hline \multicolumn{10}{|l|}{2005} \\
\hline \multicolumn{10}{|l|}{ Cultivar } \\
\hline \multicolumn{10}{|l|}{ Primocane management } \\
\hline Untipped + rowcover & 6.0 & $3.41 \mathrm{~b}$ & $83 \mathrm{~b}$ & $44.0 \mathrm{a}$ & $21.4 \mathrm{c}$ & $3.03 \mathrm{c}$ & $75.2 \mathrm{c}$ & $21.2 \mathrm{a}$ & $37.8 \mathrm{a}$ \\
\hline Tipped & 5.9 & $5.22 \mathrm{c}$ & $111 \mathrm{c}$ & $50.3 \mathrm{a}$ & $15.0 \mathrm{a}$ & $3.10 \mathrm{c}$ & $72.7 \mathrm{c}$ & $40.3 \mathrm{~b}$ & $92.6 \mathrm{c}$ \\
\hline \multicolumn{10}{|l|}{ Significance } \\
\hline Cultivar & * & NS & NS & * & $* * *$ & * & NS & NS & $* *$ \\
\hline Management & NS & $* * *$ & $* *$ & ** & $* * *$ & $* * *$ & $* * *$ & $* * *$ & $* * *$ \\
\hline $\mathrm{C} \times \mathrm{M}$ & NS & NS & NS & NS & NS & $* * *$ & $*$ & NS & $*$ \\
\hline
\end{tabular}

${ }^{\mathrm{z}}$ Main effects for cultivar and primocane management shown.

"Untipped primocane yield when grown in a "double-cropped" system with floricanes present; no data available for 2004.

${ }^{\mathrm{NS}}, *, * *, * * *$ Nonsignificant or significant at $P \leq 0.05,0.01$, or 0.001 , respectively, within year.

wMeans followed by the same letter within year are not significantly different, $P>0.05$, based on Duncan's new multiple range test.

et al., 2009). We are only reporting the primocane yield here; plantings could be double-cropped, thus adding a floricane yield of 6.1 and $4.0 \mathrm{t} \cdot \mathrm{ha}^{-1}$, respectively, for 'Prime-Jan' and 'Prime-Jim' (Strik et al., 2008).

'Prime-Jan' produced larger fruit than 'Prime-Jim' in 2004, but the opposite was true in 2005 (Table 1). Berry weight was affected by primocane management only in 2004 when soft-tipped canes produced larger fruit than UT canes (Table 1).
Fruit size in blackberry is correlated with the number of drupelets per berry and ovule set can vary among cultivars (Strik et al., 1996), especially in primocane-fruiting blackberry as a result of floral sensitivity to hot temperatures (Stanton et al., 2007). Primocane management had no effect on the total number of ovules, drupelets, or percent drupelet set in either year (data not shown). Fruit, on average, had more ovules in 2005 than in 2004 (Table 2). 'Prime-Jim' had more ovules and drupelets per berry than 'Prime-Jan' in both years of the study. In 2004, fruit harvested on 20 Aug. had more ovules and drupelets than fruit harvested on 5 Oct. (Table 2). Although there was only a 2-week difference between harvest dates in 2005, fruit harvested on the earlier date had more drupelets than lateharvested fruit. There was no effect of cultivar or harvest date on percent drupelet set, which averaged $64 \%$ and $57 \%$ in 2004 and 2005 , respectively. The drupelet set observed 
in our study was higher than the $34 \%$ and $40 \%$ set reported by Stanton et al. (2007) for 'Prime-Jim' and 'Prime-Jan' under controlled environmental conditions across a percent drupelet set found at temperatures less than $35 / 23.9{ }^{\circ} \mathrm{C}$ in their study. Temperature at bloom was estimated (50 d before harvest) to be 25 and $33{ }^{\circ} \mathrm{C}$ for early- and range of temperatures but was similar to

late-harvested fruit, respectively, in 2005 and 30 and $31^{\circ} \mathrm{C}$, respectively, in 2005 .

Cane architecture. There was a significant effect of year on the variables measured (data not shown); the main effects of cultivar and cane management are thus shown in Tables 1 and 3 by year. There was no effect of tipping on canes/plot, although the branches caused by tipping appeared to increase canopy den-

Table 2. The effect of cultivar and harvest date on the number of ovules, drupelets, and drupelet set for primocane fruiting blackberries in Oregon in 2004 and 2005. ${ }^{2}$

\begin{tabular}{|c|c|c|c|c|}
\hline $\mathrm{Yr} /$ season & Cultivar & Ovules/berry & Drupelets/berry & Drupelet set (\%) \\
\hline \multicolumn{5}{|l|}{2004} \\
\hline \multirow[t]{2}{*}{ Early (20 Aug.) } & Prime-Jan & $164 \pm 4.5$ & $101 \pm 4.0$ & 62 \\
\hline & Prime-Jim & $179 \pm 6.4$ & $114 \pm 5.6$ & 64 \\
\hline \multirow[t]{2}{*}{ Late (5 Oct.) } & Prime-Jan & $101 \pm 4.0$ & $68 \pm 2.2$ & 68 \\
\hline & Prime-Jim & $119 \pm 5.7$ & $72 \pm 2.8$ & 62 \\
\hline \multicolumn{5}{|l|}{ Significance ${ }^{y}$} \\
\hline Cultivar & & ** & NS & NS \\
\hline Harvest date & & $* * *$ & $* * *$ & NS \\
\hline \multicolumn{5}{|l|}{2005} \\
\hline \multirow{2}{*}{ Early (12 Sept.) } & Prime-Jan & $172 \pm 1.9$ & $96 \pm 10.7$ & 57 \\
\hline & Prime-Jim & $193 \pm 2.9$ & $116 \pm 10.8$ & 62 \\
\hline \multirow[t]{2}{*}{ Late (27 Sept.) } & Prime-Jan & $146 \pm 1.4$ & $77 \pm 2.7$ & 53 \\
\hline & Prime-Jim & $180 \pm 2.5$ & $95 \pm 7.4$ & 55 \\
\hline \multicolumn{5}{|l|}{ Significance } \\
\hline Cultivar & & NS & * & NS \\
\hline Harvest date & & NS & ** & NS \\
\hline Year & & * & NS & * \\
\hline
\end{tabular}

${ }^{2}$ Means averaged over primocane management treatment (mean $\pm \mathrm{SE} ; \mathrm{n}=8$; no significant effect).

${ }^{\mathrm{N} S}, *, * *, * * *$ Nonsignificant or significant at $P \leq 0.05,0.01$, or 0.001 , respectively, within year.

Table 3. The effect of cultivar $(n=16)$ and primocane management system $(n=8)$ on primocane branch yield components for primocane fruiting blackberries in Oregon in 2004 and $2005 .^{\mathrm{z}}$

\begin{tabular}{|c|c|c|c|c|c|}
\hline $\mathrm{Yr} /$ treatment & $\begin{array}{l}\text { Branches } \\
\text { (no./cane) }\end{array}$ & 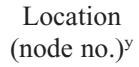 & $\begin{array}{l}\text { Total branch } \\
\text { length }(\mathrm{m})\end{array}$ & $\begin{array}{c}\text { Nodes } \\
\text { (no./branch) }\end{array}$ & $\begin{array}{c}\text { Fruit } \\
\text { (no./branch) }\end{array}$ \\
\hline \multicolumn{6}{|l|}{2004} \\
\hline \multicolumn{6}{|l|}{ Cultivar } \\
\hline Prime-Jan & 3.9 & 8.4 & 3.11 & 23.1 & 17.3 \\
\hline Prime-Jim & 4.1 & 7.9 & 3.81 & 28.1 & 15.5 \\
\hline \multicolumn{6}{|l|}{ Primocane management } \\
\hline Untipped & $3.0 \mathrm{a}^{\mathrm{v}}$ & $4.5 \mathrm{a}$ & 3.38 & $27.5 \mathrm{a}$ & 18.8 \\
\hline Primocanes + floricanes $^{\mathrm{x}}$ & - & - & - & - & - \\
\hline Untipped + rowcover & $3.8 \mathrm{a}$ & $7.9 \mathrm{~b}$ & 3.32 & $29.0 \mathrm{a}$ & 15.1 \\
\hline Tipped & $6.8 \mathrm{~b}$ & $15.5 \mathrm{c}$ & 4.08 & $17.6 \mathrm{~b}$ & 15.1 \\
\hline \multicolumn{6}{|l|}{ Significance $^{\mathrm{w}}$} \\
\hline Cultivar (C) & NS & NS & NS & * & NS \\
\hline Management (M) & $* * *$ & $* * *$ & NS & ** & NS \\
\hline $\mathrm{C} \times \mathrm{M}$ & NS & NS & NS & NS & NS \\
\hline \multicolumn{6}{|l|}{2005} \\
\hline \multicolumn{6}{|l|}{ Cultivar } \\
\hline Prime-Jan & 1.6 & 15.4 & 1.09 & 17.5 & 25.7 \\
\hline Prime-Jim & 1.8 & 16.4 & 1.36 & 17.6 & 28.9 \\
\hline \multicolumn{6}{|l|}{ Primocane management } \\
\hline Untipped & $0.7 \mathrm{a}$ & $\mathrm{NA}^{\mathrm{u}}$ & $0.51 \mathrm{a}$ & NA & NA \\
\hline Primocanes + floricanes & $1.5 \mathrm{~b}$ & 11.0 & $1.05 \mathrm{~b}$ & $26.5 \mathrm{a}$ & 18.5 \\
\hline Untipped + rowcover & $1.0 \mathrm{ab}$ & NA & $0.97 \mathrm{~b}$ & NA & NA \\
\hline Tipped & $3.3 \mathrm{c}$ & 16.5 & $2.12 \mathrm{c}$ & $16.4 \mathrm{~b}$ & 28.2 \\
\hline \multicolumn{6}{|l|}{ Significance } \\
\hline Cultivar & NS & NS & NS & NS & NS \\
\hline Management & $* * *$ & NS & $*$ & $*$ & NS \\
\hline $\mathrm{C} \times \mathrm{M}$ & NS & NS & NS & NS & NS \\
\hline
\end{tabular}

${ }^{2}$ Main effects shown.

${ }^{y}$ Average node location of all branches counting from cane base.

"Untipped primocane yield when grown in a "double-cropped" system with floricanes present; no data available for 2004

${ }^{\mathrm{w}} \mathrm{NS}, *, * *, * * *$ Nonsignificant or significant at $P \leq 0.05,0.01$, or 0.001 , respectively, within year.

'Means followed by the same letter within year are not significantly different, $P>0.05$, based on Duncan's new multiple range test.

"NA = not available; there were insufficient branches on untipped canes in 2005 to collect data on these variables. sity; canopy density has reduced primocane growth in blackberry (Cortell and Strik, 1997; Swartz et al., 1984). In 2004, UT canes produced an average of 3.4 branches/cane compared with less than one branch/cane in 2005 (Table 3). The higher incidence of "natural" branching in 2004 may have been related to a lower canopy density (fewer canes/plot) in the immature planting in 2004 than in 2005 (Table 1) as was observed in semierect blackberry (Swartz et al., 1984).

Tipping canes increased branch number to approximately seven/cane. In 2004, any branches produced on UT canes originated at node 4.5 , on average, from the cane base and were $\approx 1.1 \mathrm{~m}$ long on average (Table 3 ). Branches on tipped canes were produced near the pruned tip of the cane at node 16 and were shorter $(0.6 \mathrm{~m})$ on average.

In 2005, tipping canes increased total cane length and nodes/cane in 'Prime-Jim' but not in 'Prime-Jan' (data not shown). Branch length increased in the tipped canes in 2005 compared with 2004, perhaps as a result of greater canopy density. The number of fruit/ branch, however, was unaffected by treatment, averaging 16 to 23 , depending on year. The proportion of nodes producing fruit was greater on branches than on the "main cane" of an untipped cane, likely because the branches grow and mature faster than the top of an untipped cane, thus increasing the rate of flower bud initiation. On tipped canes, fruit were only produced on branches, as has been previously reported (Thompson et al., 2007). Tipping increased yield/cane by $114 \%$ to $150 \%$ over UT canes through increasing the number of branches/cane, nodes/cane, percent fruiting nodes, and fruit/cane (Tables 1 and 3 ).

In 2005 , using rowcovers in late winter to early spring increased yield $73 \%$ relative to uncovered canes (equivalent to $3.8 \mathrm{t} \cdot \mathrm{ha}^{-1} \mathrm{vs}$. $2.2 \mathrm{t} \cdot \mathrm{ha}^{-1}$ ). Rowcovers did not increase primocane number/plot but increased yield/cane through greater cane length and node number and a longer harvest season (Table 1).

In 2005, primocanes that grew in the presence of floricanes ("double cropping") did not have a reduced yield compared with an annual crop, agreeing with the findings of Drake and Clark (2003). Of note is that UT+F canes had a higher yield/cane, but there were fewer primocanes/plot than in the UT treatment (Table 1). The primocanes and floricanes in this type of blackberry may not compete for carbohydrates as has been noted in primocane-fruiting red raspberry (Fernandez and Pritts, 1996).

When all treatments and years were combined, yield/plot was positively correlated with the number of fruiting canes/plot, branches/ cane, fruit/cane, percent fruiting nodes, and berry weight (Table 4). It is thus important to have a high number of fruiting canes per meter of row to have high yield, as has been found in primocane-fruiting raspberry (Hoover et al., 1988). However, unlike primocane-fruiting raspberry, yield/area and yield/cane were highly correlated with the number of branches and branch length. Yield/cane was negatively correlated with the number of fruiting canes/plot 
Table 4. Correlation coefficients among vegetative and reproductive variables of primocane-fruiting blackberry in Oregon (averaged over year, cultivar, primocane management; $\mathrm{n}=64)$.

\begin{tabular}{|c|c|c|c|c|c|c|c|c|c|c|c|}
\hline & \multirow[b]{2}{*}{ Characteristic } & \multicolumn{10}{|c|}{ Characteristic } \\
\hline & & 1 & 2 & 3 & 4 & 5 & 6 & 7 & 8 & 9 & 10 \\
\hline 1) & $\begin{array}{l}\text { no. vegetative } \\
\text { canes/plot }\end{array}$ & & & & & & & & & & \\
\hline 2) & $\begin{array}{l}\text { no. fruiting } \\
\text { canes/plot }\end{array}$ & $0.479 * * *$ & & & & & & & & & \\
\hline 3) & no. branches/cane & $-0.292 *$ & $-0.411 * *$ & & & & & & & & \\
\hline 4) & Total branch length & $-0.446 * *$ & $-0.598 * * *$ & $0.829 * * *$ & & & & & & & \\
\hline 5) & Total cane length & $-0.489 * * *$ & $-0.700 * * *$ & $0.695 * * *$ & $0.935 * * *$ & & & & & & \\
\hline 6) & Total no. nodes & $-0.413 * *$ & $-0.667 * * *$ & $0.772 * * *$ & $0.899 * * *$ & $0.950 * * *$ & & & & & \\
\hline 7) & Total fruit/cane & $-0.534 * * *$ & $-0.458 * * *$ & $0.744 * * *$ & $0.809 * * *$ & $0.696 * * *$ & $0.655^{* * *}$ & & & & \\
\hline 8) & $\begin{array}{l}\text { Percent fruiting } \\
\text { nodes }\end{array}$ & NS & NS & $0.565 * * *$ & $0.328 * *$ & NS & NS & $0.613 * * *$ & & & \\
\hline 9) & Berry weight & NS & $-0.360 * *$ & $0.416 * *$ & $0.295 *$ & NS & $0.294 *$ & $0.369 * *$ & $0.257^{*}$ & & \\
\hline 10) & Yield/plot & NS & $0.352 * *$ & $0.415 * *$ & NS & NS & NS & $0.304 *$ & $0.522 * * *$ & $0.356^{* *}$ & \\
\hline 11) & Yield/cane & NS & $-0.558 * * *$ & $0.723 * * *$ & $0.695 * * *$ & $0.592 * * *$ & $0.636 * * *$ & $0.653 * * *$ & $0.345^{* *}$ & $0.672 * * *$ & $0.438 * * *$ \\
\hline
\end{tabular}

NS, ${ }^{*}, * *, * * *$ Nonsignificant or significant at $P \leq 0.05,0.01$, or 0.001 , respectively.

but positively correlated with branches/cane, total branch and cane length, number of nodes and percent fruiting nodes, fruit/cane, percent fruiting nodes, and berry weight. Tipping increased branch number and thus yield in both cultivars of primocane-fruiting blackberry.

\section{Conclusions}

'Prime-Jan' and 'Prime-Jim' primocane fruiting blackberry responded similarly to primocane management treatments. Untipped primocanes grown for only the primocane crop had a similar yield and fruiting season than those grown in a double-cropped system in the presence of floricanes. Rowcover, when placed on plots early enough in late winter, advanced the fruiting season and increased yield compared with uncovered plants, because more fruit could be harvested before frost in the fall; rowcover did not increase the number of primocanes per meter of row.

Soft-tipping, when done before any evidence of the presence of apical floral buds, increased yield without delaying fruit harvest. The proportion of nodes producing fruit on cane branches was more than on the main cane. Management practices such as tipping that increase branch number will increase yield per cane. Although untipped canes did produce branches, tipping increased the number of branches and moved their origin from near the base of the main cane to near the point of tipping.

\section{Literature Cited}

Anonymous, 2012. U.S. Department of the Interior, Bureau of Reclamation, Boise, ID. Agrimet Weather Station 5 Feb. 2012. <http://www.usbr. gov/pn/agrimet/agrimetmap/araoda.html $>$.

Carew, J.G., K. Mahmood, J. Darby, P. Hadley, and N.H. Battey. 2003. The effect of temperature, photosynthesis photon flux density, and photoperiod on the vegetative growth and flowering of 'Autumn Bliss' raspberry. J. Amer. Soc. Hort. Sci. 128:291-296.
Clark, J.R., J.N. Moore, J. Lopez-Medina, C. Finn, and P. Perkins-Veazie. 2005. 'Prime-Jan' ('APF8') and 'Prime-Jim' ('APF-12') primocane-fruiting blackberries. HortScience 40:852-855.

Clark, J.R. and P. Perkins-Veazie. 2011. 'APF-45' primocane-fruiting blackberry. HortScience 46:670-673.

Cortell, J.M. and B.C. Strik. 1997. Effect of floricane number in 'Marion' trailing blackberry. II. Yield components and dry mass partitioning. J. Amer. Soc. Hort. Sci. 122:611-615.

Darnell, R.L., B. Brunner, H.E. Alvarado, J.G Williamson, M. Plaza, and E. Negrón. 2006. Annual, off-season raspberry production in warm season climates. HortTechnology 16:92-97.

Drake, C.A. and J.R. Clark. 2003. Effects of pruning and cropping on field-grown primocane-fruiting blackberries. HortScience 38:260-262.

Fernandez, G.E. and J.R. Ballington. 2010. Performance of primocane-fruiting experimental blackberry cultivars in the Southern Appalachian Mountains. HortTechnology 20:996-1000.

Fernandez, G.E. and M.P. Pritts. 1996. Carbon supply reduction has a minimal influence on current year's red raspberry (Rubus idaeus L.) fruit production. J. Amer. Soc. Hort. Sci. 121:473-477.

Hoover, E., J. Luby, D. Bedford, and M. Pritts. 1988. Vegetative and reproductive yield components of primocane-fruiting red raspberries. J. Amer. Soc. Hort. Sci. 113:824-826.

Jordan, D. and J. Ince. 1986. Primocane tipping to programme production in fall (autumn) cropping raspberries. HortScience 21:775 (abstr.).

Lopez-Medina, J. and J.N. Moore. 1999. Chilling enhances cane elongation and flowering in primocane-fruiting blackberries. HortScience 34:638-640.

Lopez-Medina, J., J.N. Moore, and K.-S. Kim. 1999. Flower bud initiation in primocane-fruiting blackberry germplasm. HortScience 34:132-136.

Oliveira, P.B., C.M. Oliveira, L. Lopes-da-Fonseca, and A.A. Monteiro. 1996. Off-season production of primocane-fruiting red raspberry using summer pruning and polyethylene tunnels. HortScience 31:805-807.

Oliveira, P.B., C.M. Oliveira, P.V. Machado, L. Lopes-da-Fonseca, and A.A. Monteiro. 1998. Improving off-season production of primocanefruiting red raspberry by altering summer pruning intensity. HortScience 33:31-33.
Pritts, M., E. Hanson, J. Fiola, and M.J. Kelly. 1992. Rowcovers accelerate fruiting and increase productivity in primocane-fruiting red raspberries. HortTechnology 2:46-51.

Privé, J.-P., J.A. Sullivan, J.T.A. Proctor, and O.B. Allen. 1993. Climate influences vegetative and reproductive components of primocane-fruiting red raspberry cultivars. J. Amer. Soc. Hort. Sci. 118:393-399.

Richter, R., M. Kaps, and M. Odneal. 1989. Approaches to problems with the harvest season of 'Heritage' red raspberry in Missouri or isn't a fall-bearer supposed to bear in fall? Proc. 1989 Missouri Small Fruit Conf. p. 26-38.

Sønsteby, A. and O.M. Heide. 2009. Effects of photoperiod and temperature on growth and flowering in the annual (primocane) fruiting raspberry (Rubus idaeus L.) cultivar 'Polka'. J. Hort. Sci. Biotechnol. 84:439-446.

Stanton, M.A., J.C. Scheerens, R.C. Funt, and J.R. Clark. 2007. Floral competence of primocanefruiting blackberries Prime-Jan and Prime-Jim grown at three temperature regimes. HortScience 42:508-513.

Strik, B.C., J.R. Clark, C.E. Finn, and G. Buller. 2008. Management of primocane-fruiting blackberry to maximize yield and extend the fruiting season. Acta Hort. 777:423-428.

Strik, B.C., J. Mann, and C.E. Finn. 1996. Drupelet set varies among blackberry genotypes. J. Amer. Soc. Hort. Sci. 121:371-373.

Strik, B.C. and E. Thompson. 2009. Primocanefruiting blackberries - Potential for extending harvest season and production regions. HortScience 44:23-24.

Swartz, H.J., S.E. Gray, L.W. Douglass, E. Durner, C.S. Walsh, and G.J. Galletta. 1984. The effect of a divided canopy trellis design on thornless blackberry. HortScience 19:533-535.

Thompson, E., B.C. Strik, J.R. Clark, and C.E. Finn. 2007. Flowering and fruiting patterns of primocane-fruiting blackberries. HortScience 42:1174-1176.

Thompson, E., B.C. Strik, C.E. Finn, Y. Zhao, and J.R. Clark. 2009. High tunnel vs. open field: Management of primocane-fruiting blackberry using pruning and tipping to increase yield and extend the fruiting season. HortScience 44:15811587. 